\title{
Overview of the Leather Industry and Pollution Impact
}

\author{
Vânia F. M. Silva ${ }^{1}$ \\ ${ }^{1} \mathrm{CIETI}-$ Center for Innovation in Engineering and Industrial Technology, ISEP-School of \\ Engineering, Polytechnic of Porto, Rua Dr. Antonio Bernardino de Almeida, 431, 4249-015 \\ Porto, Portugal; Doctoral program in Chemistry, Faculty of Sciences, University of Porto, Porto, \\ Portugal (vfmsi@isep.ipp.pt) ORCID 0000-0001-9513-3049
}

\begin{abstract}
The growing awareness of the human and environmental vulnerability, to the pollution resulting from industrial activity, highlights the urgent need for control and mitigate the degradation of the world as we know it. The leather industry, considered as one of the industries with a significant environmental impact, applies several chemicals, some of them considered as hazardous chemicals, such as chromium, in leather production. The restricted EU environmental regulations have driven the search for a process that ensures regulatory compliance and a final product that fulfills society's requirements. The present review describes alternative options, applied in the leather tanning process in the last five years, to overcome some of the industry barriers, without compromising the final characteristics of leather.
\end{abstract}

Author Keywords. Leather, Tanning Pollution, Environmental Impact, Chromium Tanning.

Type: Review Article

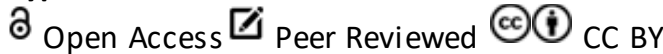

\section{Introduction}

Leather, manufactured from the animal's skin (sheep, goat, or pig) or hides (cattle and buffalo), is applied in a large class of items used in daily human life since the very beginning.

With a rapid development to maintain the upward trend of society requirements, the leather industry tries to combine different dimensions: product features, economic growth, and environmental protection (LWG 2019).

As an intermediate product, transformed into different articles, the main application of leather relates to footwear, with $41 \%$ of EU market, followed by $19 \%$ of leather goods, furniture (17\%), automotive articles (13\%), clothes (8\%) and others (2\%) (COTANCE 2016; European Commission 2019).

Playing an essential socio-economic role, the leather industry with about 36,000 enterprises, present turnover of EUR 48 billion (European Commission 2019), and an average production of leather, from bovine hides, of more than 558 thousand tons in the world (FAO 2016). Between 2012 and 2014, 444 thousand tons of bovine hides belong to the developing countries, and near 114 thousand tons to the developed countries (20.5\% of the world market in Europe) (FAO 2016).

In 2018, Italy had by far the most significant exportation trade of finished leather, representing $33.6 \%$ of the world's total exportations, and $54.1 \%$ on Europe (Conseil National du Cuir 2019). In the same year (Figure 1), Portugal assumed the $32^{\text {nd }}$ place in the exportation, in which its two top clients (Spain and France) have, respectively, $19.4 \%$ and $19.1 \%$ of the intern market (Conseil National du Cuir 2020). 


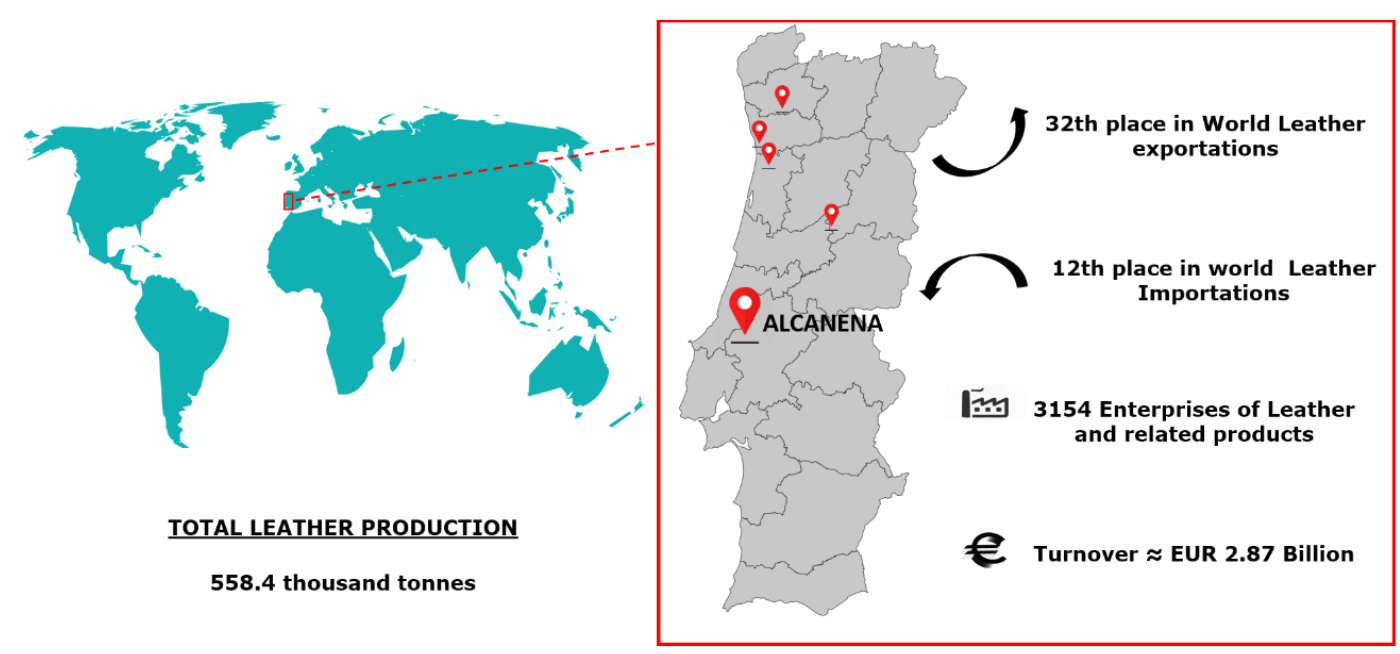

Figure 1: Total leather production in the world and leather market in Portugal (FAO 2016; Statista 2020a, 2020b)

According to available data, in 2016, a total of 3154 enterprises were involved in the manufactured leather and related products in Portugal (Statista 2020a), resulting in a turnover of 2.83billion euros (Statista 2020b).

Therefore, it can be said that the leather industry's importance is broadly positive, showing the social and economic benefits in our daily lives.

On the other hand, from an environmental point of view, its impact is not so positive.

Even though the recovery of animal skin discarded by the meat industry may refer to the concept of a circular economy, the pollutants used in the leather tanning process have a profound effect on the environment (Joseph and Nithya 2009).

The present review provides an overview of the leather industry and its significant pollution impact in the environment, and which solutions were proposed in the last five years to convert it to a greener and sustainable process.

\section{Leather Tanning Process Stages}

Through a long tradition and experience, the leather production consists of a set of physicalchemical and mechanical operations to transform the hides (skins from larger animals - cattle and buffalo) and skins (from smaller animals - goat, pig, sheep) into leather (Covington 2011). The leather tanning process is divided into three stages: pre-tanning, tanning, and posttanning.

\subsection{Pre-tanning process operations}

Pre-tanning process operations (Figure 2) prepare the skin to receive the tanning agents, and eliminate all the elements unsuitable to the tannery (Covington 2011). The process starts with the selection of hides and skins after animal slaughter, followed by skin preservation. Susceptible to microbial attack, the skin and hides are preserved in salt, usually with 40 to 50 wt\% of sodium chloride, preventing its putrefaction (Sarker et al. 2018; Hashem, Momen, and Hasan 2018). Skin rehydration, blood, and excrements residues removal are ensured by a large amount of water, surfactants, and bactericides, added to the soaking step (Covington 2011). Subsequently, an alkaline bath containing sulfur, supplied by lime (10-20 wt\%) and sodium sulfide (2-5 wt\%) (Kanagaraj et al. 2015) allows the skin dehairing, and swelling of skin structure to remove non-collagenous proteins (Sujitha et al. 2018). The presence of lime (calcium hydroxide - $\mathrm{Ca}(\mathrm{OH})_{2}$ ) is essential to maintain an equilibrium between the sulfide species, preventing the formation of hydrosulfide, and consequent deceleration of the hair 
removal process (Covington 2011). After dehairing, a mechanical process - Fleshing - removes subcutaneous and adipose tissues of the skin by the action of roller slides (Dixit et al. 2015).

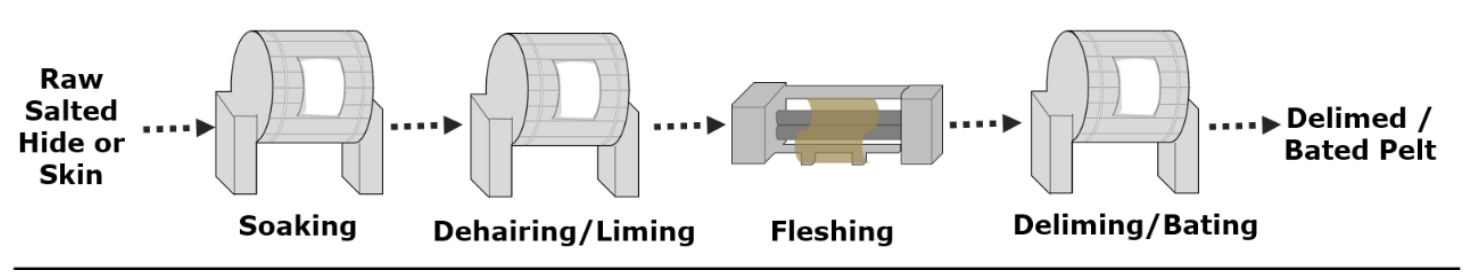

Figure 2: Pre-tanning operations process (Covington 2011)

Neutralization of the residual lime (Deliming operation), occurs with acids, ammonium, and acidic salts, followed by a reaction with proteolytic enzymes (Bating), resulting in the bated pelt (Covington 2011).

\subsection{Tanning process operations}

The tanning operation (Figure 3) converts the bated pelt into a stable material against microorganism attack, mechanical stress, and wet heat effect (hydrothermal stability) (Covington 2011). The operations starts with the pickling step, in a saline solution at pH 2.53.0, where the bated pelt is prepared to tanning. The saline solution is ensured by at least 6 wt\% of sodium chloride, to prevent the acid swelling and consequent damage of the skin structure. The lowest pH (2.5-3.0) provided by sulfuric and formic acids (Zhang et al. 2016), increases the ionic charges at the amino groups of skin. The positively charged skin provide an increasing osmotic pressure within the pelt, compared to the external medium. Therefore, there would be a diffusion of the aqueous medium into the pelt, enhancing the skin swelling and its sensibility towards the heat and mechanical stress. To counterbalance, an excess of electrolyte provided by the salt prevent the swelling effect and ensures a uniform tanning (Covington 2011; Sundar, Muralidharan, and Mandal 2013).

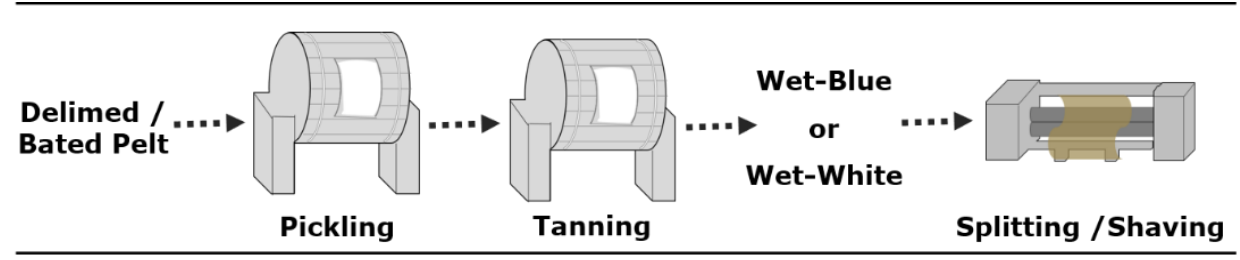

Figure 3: Tanning process operations (Covington 2011)

Traditionally, the tanning process applies chromium salts as tanning agents. Around $85 \%$ of all leathers are produced with chrome-based process technology (Crudu et al. 2014).

In chromium tanning, the pelt stabilized with chromium sulfate (6 to $8 w t \%)$, through a covalent reaction with the ionized carboxyl groups of skin (Figure 4), is referred to as Wet-blue (Covington 2011; Zhang et al. 2016). On the other hand, Wet-white classifies the chrome-free leather. Other tanning processes, with similar operation steps, can apply vegetable extracts, synthetic tannins, other mineral compounds, aldehydes, or a mixture of these agents (Dixit et al. 2015; Cao et al. 2017).

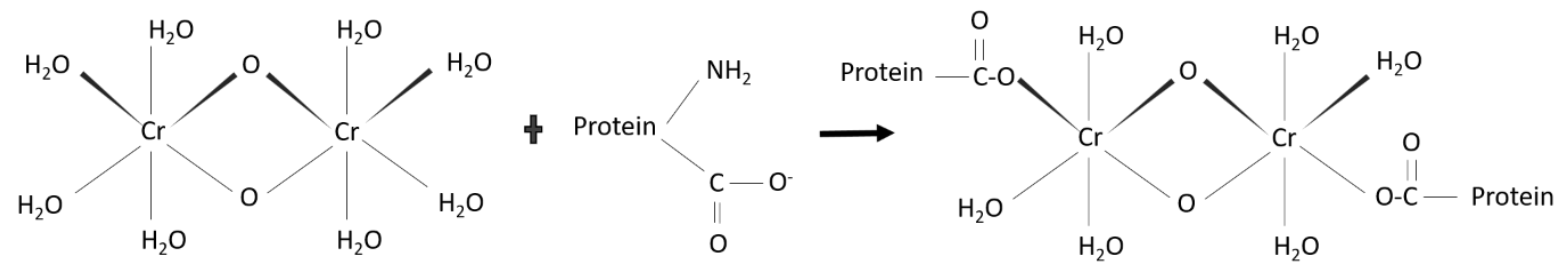

Figure 4: Mechanism of protein skin complexation with chromium

(Bacardit et al. 2008) 
A mechanical operation ends the tanning phase. The leather is split and shaved to a desired and uniform thickness (Covington 2011).

\subsection{Post-tanning process operations}

In order to impart color, texture, brightness, and other physical characteristics, the wet-blue or wet-white is post-tanned. The tanned pelt is re-tanned with additional tanning substances (vegetable extracts, synthetic tannins, and resins). Then it is dyed and fatliquored to provide softness to the touch and tear resistance. Mechanical operations complete the process, which offers the final surface coating (Covington 2011; Dixit et al. 2015).

\section{Leather Industry: Environment Scenario}

The leather production uses high amounts of chemical agents and water and, therefore, is often associated with the production of greenhouse gases, high amounts of solid waste, and high organic loads in the wastewater (Dixit et al. 2015; Giaccherini et al. 2017). It is described that in one metric ton of rawhide tanned, only $20 \%$ is transformed into the leather (Figure 5) (Tahiri 2009).

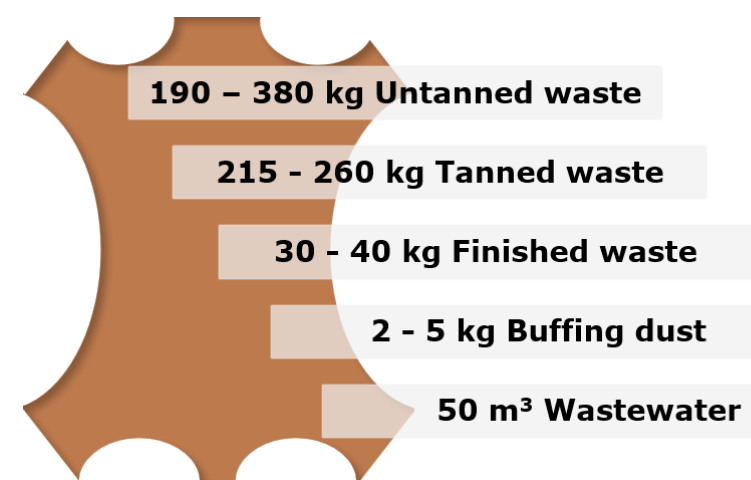

Figure 5: Distribution of leather wastes and wastewater loads (Tahiri 2009)

Pre-tanning and tanning operations are responsible for $57 \%$ of water consumption in the industry (Kanagaraj et al. 2015), and near $90 \%$ of the tannery pollution (Dixit et al. 2015). The pollution load is mainly characterized by the presence of sulfides, chlorides, sulphates, chromium, high content of organic matter, and solids wastes (Dixit et al. 2015). Therefore, considering the preponderant role in this problematic, it will only be described as the environmental scenario for these stages of leather production.

\subsection{Pre-tanning process impact}

Prepare the skin for the tanning stage induces high discharges of untanned wastes, such as: hair debris, fleshing, and hide residues. For each metric ton of tanned hide, between 190 to $380 \mathrm{~kg}$ of waste are released to effluents (Tahiri 2009). According to Ramesh, Muralidharan, and Palanivel (2018), fleshings contribute to a one-third volume of the solid wastes, generated in the leather tanning process. Moreover, the presence of these solid wastes conduces to a sludge problem and blockage of waste collection systems (Covington 2011; Kanagaraj et al. 2015).

In addition to the untanned wastes, the pre-tanning process is also characterized by an alkaline medium with high saline and sulfide contents. The high saline content, resulting mainly from the preservation and soaking step, impacts the viability of the organisms in different ecosystems (Kanagaraj et al. 2015; Hülsen, Hsieh, and Batstone 2019). The deposition of highly salinized wastes in the soil disturbs the plant growth. Ion competitions, insufficient uptake of nutrients, and reduced water accessibility, by increased osmotic pressure, results from the toxic effect of sodium and chloride ions (Miransari 2017). Furthermore, biological treatments efficiency also decreases, with a loss of microbial activity 
in the presence of high saline wastewaters (Kargi and Dincer 1996). On the other hand, the sulfide content results from the application of sodium sulfide on dehairing process. Considered as chemical hazardous, the sodium sulfide, under pH9.5, is capable of releasing hydrogen sulfide: a toxic gas with an obnoxiously odorous; a high capability to corrode the structure of the sewer; and cause headaches, nausea, and quick death (Bosnic, Buljan, and Daniels 2000; Pang et al. 2017).

Literature reveals that the pollution load of this phase contributes to a total of $80-92 \mathrm{wt} \%$ of suspended solids, $100 w t \%$ of sulfide, $84 \mathrm{wt} \%$ of biochemical, and $75 \mathrm{wt} \%$ of chemical oxygen demand (Dixit et al. 2015; Morera et al. 2011).

\subsection{Tanning process impact}

Reduced uptake of chemicals by the skin are particularly harmful, especially when it comes to the heavy metals. Chromium, considered as one of the 129 top priority pollutants (EPA 2014), can be found in water, soil, and air (Tchounwou et al. 2012). A significant presence of chromium, averaging 60 to $80 \%$ of the leather uptake, is found in the released effluent and solid waste (Crudu et al. 2014; Zhang et al. 2016). Chrome shavings represent $75 \%$ of the chromium solid wastes, with an estimated production of 0.8 million ton/year (Erdem 2006), that ended up in landfills (Zuriaga-Agustí et al. 2015) or incinerated (Rao et al. 2002).

According to Dixit et al. (2015), during the process of 1 tonne of hide, 2 to $5 \mathrm{~kg}$ of chromium is also released into wastewater. Even though the intake of 50-200 $\mu \mathrm{g}$ is recommended for our physiological activity, the occurrence in excess plays a toxic role to human health (Chandra and Kulshreshtha 2004). Moreover, the trivalent chromium form can be oxidized to the carcinogenic form, the chromium(VI) (Chandra and Kulshreshtha 2004; Tchounwou et al. 2012). According to the Commission Regulation, No 301/2014 - annex XVII, if the chromium $\mathrm{VI}$ concentration is superior to $3 \mathrm{mg} / \mathrm{kg}$ of the total dry weight of the leather in contact with skin, the leather cannot be commercialized (European Commission 2014). These daily adverse health effects that tannery workers are exposed by inhalation, cutaneous contact, and possible ingestion is a concern shared by the industry and the public authorities (Rastogi, Pandey, and Tripathi 2008; Syed et al. 2010). Additionally, the high negative impact on the environment, has led to several types of research to achieve greener technologies.

\section{Alternative Mechanisms to Achieve Sustainability}

The escalation in the requirement of goods and production of wastes has called for action all the countries. To develop an economic, social, and environmentally sustainable system that does not compromise the needs of future generations, 17 goals were proposed to achieve by the year 2030 (United Nations 2016). The ambitious commitment to the 2030 Agenda for Sustainable Development has also committed the leather industry to improve its environmental footprint. The goals to reduce the health side effects and the pollution impact in the environment, by the management of hazardous chemicals life cycle with prevention, minimization, and its elimination, is one of the main concerns of the industry. The adoption of a "guidance document that provides tanners and leather producers information on suggested best environmental practices" comprises all the partners involved in the leather manufacture cycle (LWG 2019).

Alternative technologies, with combination or even replacement of conventional products, are being considered to mitigate the environmental impact of the leather tanning industry. The success of these processes depends, among other properties, on the quality of the effluent. Parameters such as sulfide, chloride, organic matter, solids, and heavy metals are 
tested to characterize the pollution load of each process (Zhang et al. 2017a; Hashem et al. 2017).

\subsection{Preservation methods}

Untreated skin starts its degradation within 5 to 6 hours after animal slaughter (Hashem et al. 2017). Therefore, preservation is essential to halt the degradation process. Common salt is the preferred preservation compound. In 2017 and 2018, a less-salt technology explored the leaf of two plant species, Clerodendrum viscosum (Hashem et al. 2017) and Moringa oleifera (Hashem, Momen, and Hasan 2018). With biocidal properties, both species combined with $10 \%$ of sodium chloride achieved better results than the conventional sodium chloride application of $50 \mathrm{wt} \%$. The experiment with $M$. oleifera showed better preservation characteristics, and lower pollution load with less $46 \mathrm{wt} \%$ of chlorides and $39 \mathrm{wt} \%$ of total dissolved solids (TDS) (Hashem, Momen, and Hasan 2018).

\subsection{Dehairing methods}

Numerous practices can also be found in the literature describing alternatives to chemical dehairing. Oxidative technologies, enzymatic process, or a combination of methods has been approached.

Morera, Bartolí, and Gavilanes (2016) performed a modification on the conventional process, applying hydrogen peroxide as a partial substitute for sulfide. An input of $3 \%$ of hydrogen peroxide was enough to hydrolyze the keratin, completing the hair removal initiated with the lime and sulfide process. Results showed a reduction of pollution load in the effluents, in $26 \%$ of conductivity, and $75 \%$ on suspended solids, for 2 hours operation. In the same year, Kanagaraj, Panda, and Senthilvelan (2016) carried out the dehairing process with the help of sodium percarbonate (Figure 6) and sodium hydroxide. A reduction of more than $50 \%$ of the pollution load was observed. In this study, the hair was removed entirely under alkaline conditions, between pH 11.5 to 12, after 16 hours (Kanagaraj, Panda, and Senthilvelan 2016). Enzymes technology have also been developed for hair removal, allowing its recovery for further applications (Vijay Kumar et al. 2011; Andrioli, Petry, and Gutterres 2015).

Andrioli, Petry, and Gutterres (2015) compared an enzymatic-oxidative process with a purely enzymatic method. Crude enzyme extract produced by the strain Bacillus subtilis BLBC 11 was used in the tests. In all the methods, the hair was removed. However, the efficiency removal was higher in the combination of oxidative ( $8 \mathrm{wt} \%$ of hydrogen peroxide) and enzymatic protocols (300U/g hide of enzymatic extract). It was also found that both techniques do not destroy the hair and are more environmentally friendly than the lime-sulfide practice. Furthermore, the time reduction from 15 hours to 6 hours and 2 hours, from standard dehairing to purely enzymatic and combined systems, respectively (Andrioli, Petry, and Gutterres 2015), showed the benefits of alternative approaches.

An attempt to use carbohydrases to accelerate the processing time, and improve the fiber opening with the elimination of lime, has been explored (Durga et al. 2016; Jayanthi et al. 2019). A noticeable improvement in the environmental area was observed, with reductions up to $80 \%$ on the usual parameters: chemical oxygen demand (COD); biochemical oxygen demand (BOD); and total dissolved solids (Jayanthi et al. 2019). In the case of Durga et al. (2016), the COD reduction achieved $90 \%$, while TDS only $60 \%$. Nevertheless, the considerable difference between both processes lies in time operation and enzyme concentration. For Durga et al. (2016), 30 min duration with 0.5 wt\% of carbohydrase was sufficient, while for Jayanthi et al. (2019), the process was considered complete after 24 hours with 1 wt\% of carbohydrase. 
Anzani et al. (2017) compared the efficiency of an alcalase, from Bacillus licheniformis, against an oxidative method with sodium hydroxide and hydrogen peroxide. To guarantee an effective and uniform action of the alcalase, the adipose layer was removed before the enzymatic process occurred. With buffered $\mathrm{pH}$ at 7 and temperature of 40 Celsius degrees, the alcalase ( $2.4 \mathrm{U} / \mathrm{g}$ solution, $1 \%(\mathrm{v} / \mathrm{w}$ of skin)) needed 22 hours to complete the dehairing process. However, some traces of hair remained in the subcutaneous layer when compared to the oxidative protocol, where the hair was disintegrated entirely after 13 hours at pH 13 (Anzani et al. 2017).

In the same year, Ranjithkumar et al. (2017) also studied the action of an proteolytic enzyme (bacteria Bacillus crolab MTCC 5468) in dehairing over a range of conditions, such as concentration, $\mathrm{pH}$ and time. Complete removal of hair follicles was observed to occur with 1.2 wt\% enzyme concentration. From the data found, it was concluded that the rate of dehairing was more significant with the increase of enzyme concentration, and to only a limited extent, with increasing $\mathrm{pH}$ and exposure time. The rate is progressive under alkaline conditions ( $\mathrm{pH} 9)$ and increasing time, obtaining a complete removal in 4hours of treatment. Moreover, it was observed that longer treatments damage the skin (Jian, Wenyi, and Wuyong 2011; Ranjithkumar et al. 2017), by loosening the corium structure (Covington 2011).

In a circular economy perspective, the integration of solid leather wastes was also approached. Fleshings and wet-blue shavings, have been studied as auxiliaries in protease production for hair removal applications.

Ramesh, Muralidharan, and Palanivel (2018) evaluated the use of fleshings as an additional source of carbon and nitrogen to increase the protease activity in the dehairing process. The enzyme exhibits its maximum activity $(956 \mathrm{U} / \mathrm{g}$ ) using $6 \mathrm{wt} \%$ of fleshing hydrolysate powder, at pH9. Exposure of the animal skin to this protease achieved its complete dehairing in 7 hours of treatment, with $25 \mathrm{wt} \%$ of enzymes. Pollution parameters showed a reduction of $79.6 \mathrm{wt} \%$ of COD and 67.7 wt\% of BOD (Ramesh, Muralidharan, and Palanivel 2018).

A similar study was performed with chrome shavings. The presence of chrome shaving's hydrolysate not only served as a protein source, in the protease production by Bacillus cereus VITSN04, but also improved its stability. Although, the environmental impact from this process has not been assessed, the application on hair removal showed excellent results (Shakilanishi, Chandra Babu, and Shanthi 2017).

From all the alternative dehairing mechanisms, the application of enzymes presents itself as one of the most promising methods (Andrioli, Petry, and Gutterres 2015) to fulfill the goals for sustainable development.

The exposure of skin to enzymatic techniques not only showed a clear reduction in pollution load but also demanded less time to complete the process, which translates to a drop in the energy cost when compared to the standard method. Even though enzyme production is not economical (Ramesh, Muralidharan, and Palanivel 2018), the exploitation of the generated wastes throughout their life cycle by reusing solid leather wastes, reduce the hazardous environmental impact, and encourages responsible consumption and production (United Nations 2016). Furthermore, the use of enzymes allows hair recovering for further applications, contrary to the oxidative method, which destroys the hair (Andrioli, Petry, and Gutterres 2015) and brings a new concern: the hydrogen peroxide poisoning (Watt, Proudfoot, and Vale 2004). 


\subsection{Tanning methods}

To overcome the sodium chloride environmental problem, in the pickling effluents, different mechanisms were explored to ensure that no ecological disturbance occurs. Recycling of pickling liquor (Sivakumar et al. 2005) and salt-free pickling process (Li et al. 2009; Zhang et al. 2016; Sundar and Muralidharan 2017; Zhang et al. 2017a; Zhang et al. 2017b; Jia et al. 2020) are the answers presented so far.

In recent studies, mechanisms without application of neutral salt boosted the research.

Zhang et al. (2016) applied naphthalene sulfonic acid, naphthol sulfonic acid, phenol sulfone sulfonic acid, and sulfosalicylic acid, in the pickling step, instead of sulfuric and formic acid. The results showed that the application of sulfonic acids (Figure 6) not only prevented the acid swelling, but also ensured a higher uptake of chromium by the pelt. Chromium reduction from $1636.7 \mathrm{mg} / \mathrm{L}$ in spent pickling liquor to values of $423.9 \mathrm{mg} / \mathrm{L}$ was observed. The authors also conducted an exhaustive study with naphthalene sulfonic acid, achieving a chromium uptake of $98.4 \%$ against the conventional $73.1 \%$, and a significant decrease for chromium emission of $36.5 \mathrm{mg} / \mathrm{L}$ (Zhang et al. 2016).

Similar results were obtained in a study involving a synthetized sulfonic aromatic acid (Zhang et al. 2017b), highlighting the advantages of these compounds.

In a recent contribution, Jia et al. (2020) studied whether an epoxy compound and urotropine (Figure 6) were able to prevent skin swelling in the pickling step. Polyoxyethylene diepoxy ether (PODEE) and urotropine were tested individually and combined, at $\mathrm{pH}$ 2.8-3.0 and different dosages. The combination of both compounds ( $0.5 \%$ urotropine and $4 \%$ PODEE) not only allowed the prevention of acidic swelling but also minimized the presence of chromium in disposable facilities. From the pilot-scale trials, emission reductions of $15 \%$ of COD and $42 \%$ of TDS were observed. Near $280 \mathrm{mg} / \mathrm{L}$ of residual chromium was determined in the effluent with an offer of 0.89 wt\% and an uptake of $91.3 \%$ (Jia et al. 2020).<smiles>O=S(=O)(O)c1cccc2ccccc12</smiles>

Naphthalene sulfonic acid<smiles>[NH3+][OH+]OC(=O)[OH2+]</smiles>

Sodium percarbonate<smiles>O=S(=O)(O)c1ccc2ccccc2c1O</smiles>

Naphthol sulfonic acid<smiles>O=C(O)c1cc(O)ccc1OS(=O)(=O)O</smiles>

Sulfosalicylic acid

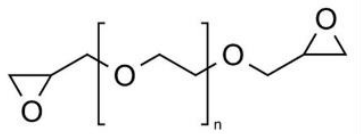

Polyoxyethylene diepoxy ether

Figure 6: Molecules structure used in alternative methods: Naphthalene sulfonic acid; Naphthol sulfonic acid; Sulfosalicylic acid; Sodium percarbonate; Urotropine; and Polyoxyethylene diepoxy ether

Researchers also explored chromium recovery systems and its reintroduction in the tanning process. Chromium recovery occurs with sulfuric acid addition in the sludge, after salt precipitation, with liquid or solids alkalis (Erdem 2006; Morera et al. 2011). Despite the chrome recovery, its appliance needs to satisfy the basicity requirement of $33 \%$ (Liu et al. 2016), to bind with the carboxylic groups of the collagen and achieve the ideal tanning effect (Covington 2011; Cao et al. 2018).

Zhang et al. (2017a), to minimize the chromium discharged, associate two alternative systems: the salt-free process, performed with naphthalene sulfonic acid, and the recycling of chrome tanning effluent. From the data found, it was concluded that the recycling process has a 
limited extent of ten cycles. Also, the association of these systems allowed $98.6 \%$ of chromi um uptake. Total chromium discharged of $4.604 \mathrm{~g} /$ ton of the salted hide ( $84.2 \%$ of reduction), and a reduction of its presence in the sludge in $28.1 \%$ was also observed (Zhang et al. 2017a).

According to Cao et al. (2018), frequent recycling cycles converge into the minimization of chromium concentrations in the wastewater. Less than $5 \mathrm{mg}$ of chromium/L after 20 cycles were determined in the effluent. The removal of organic substances from the effluents, and chromium basicity adjustments are recommended before its recycling (Erdem 2006; Cao et al. 2018).

From the brief account of tanning alternatives presented in the last five years, single chromefree tanning options, such as titanium (Zuriaga-Agustí et al. 2015), aluminum (Gao et al. 2020) and others combined tanning agents (Silva, Crispim, and Pinto 2019; Gao et al. 2020; Sundar and Muralidharan 2020) were considered as promising substitutes to the chromium sulphate. A significant reduction in the environmental pollution was verified by the authors, except for Silva, Crispim, and Pinto (2019) and Gao et al. (2020), where this assessment was not considered.

In addition, alternative emerging options using mineral clay nanoparticles, as auxiliaries to the leather tanning process have been suggested. Liu et al. (2016) investigated the montmorillonite application, a natural clay structure with 50 to $500 \mathrm{~nm}$ of diameter, on a chrome tanning process. Offered before the chromium introduction, the montmorillonite enhance the chromium uptake, and reduce the chromium discharge from $2032.9 \mathrm{mg} / \mathrm{L}$ to $165.6 \mathrm{mg} / \mathrm{L}$. A Significant decrease of pollution load was observed with the reduction of chromium offer from 8 wt\% to 3 wt\% (Liu et al. 2016).

Even though the ecological footprint reduction is essential, the ultimate leather characteristics are also relevant in the process evaluation. Tear and tensile strength, and hydrothermal stability are some of the leather properties that are strictly related to the process efficiency, and consequent leather durability (Sundar and Muralidharan 2017). Therefore, an alternative and sustainable technology will only be considered if the leather properties are comparable to the values achieved with the conventional chrome tanning process (Covington 2011).

Although the elimination of hazardous compounds is the ideal solution, the implementation of chromium-free processes is unlikely to occur due to the significant difference between expected results and those obtained. While the chrome leather is stable until an average of $110^{\circ} \mathrm{C}$, the presented alternatives were stable until $62.1^{\circ} \mathrm{C}$ with aluminum (Gao et al. 2020), 83.1 으 with titanium (Zuriaga-Agustí et al. 2015), and a maximum of 88ㅇ with combined tanning agents (Silva, Crispim, and Pinto 2019; Sundar and Muralidharan 2020). Also, the leather tear and tensile strength were bellow the values obtained with the standard process (Zuriaga-Agustí etal. 2015; Silva, Crispim, and Pinto 2019; Sundar and Muralidharan 2020; Gao et al. 2020). Thus, if the options rely not on the elimination but minimizing problematic compounds, the addition of auxiliaries as nanocomposites presents higher results on leather properties. However, the removal of other compounds, such as the neutral salt, has not been addressed, maintaining the salinization problem (Liu et al. 2016).

Nevertheless, considering the salt-free pickling processes without eradicating the chromium, most of the studies improved the values obtained on leather properties characterization. Denaturation temperatures between 111으 (Jia et al. 2020) and 125.1으 (Zhang et al. 2017a), tear strength increases of 3.1\% (Jia et al. 2020) to 25\% (Zhang et al. 2016), and percentages of tensile strength above the conventional process values, between 1.2\% (Zhang et al. 2017a) and 46.2\% (Zhang et al. 2016) were achieved. However, the combination of urotropine and 
PODEE presented the worst results in these studies, especially for the tensile strength, which values stayed below the standard (Jia et al. 2020). Furthermore, when compared with all the researches, the implementation of aromatic sulfonic acids associated with chromium exhaustion by its recycling showed the highest stability for all the evaluated parameters (Zhang et al. 2016; Zhang et al. 2017a).

Therefore, in search of alternative technologies that support an ecological responsibility without undermining the tanning industry targets, the tanning agents presented as chromium substitutes, for the time, will not be fully embraced by the industry. Hence, with a process cost reduction of $49.6 \%$ (Zhang et al. 2017a), the best option to fulfill the 2030 Agenda goals for Sustainable Development, relies on the conscientious management of compounds with a circular approach, with salt replacement by aromatic sulfonic acids and chromium life cycle expansion.

\section{Conclusions}

There is no doubt that the leather, and its related industries, play an important socioeconomic role in the world, on account of its substantial trade market and employment opportunities.

Based on the transformation of a by-product of the meat industry, a set of physical-chemical operations are applied to convert the animal skin into a durable and flexible material. Several critical parameters are used to evaluate the leather tanning process efficiency. Environmental impact, leather mechanical, and hydrothermal resistance are some of the focal points in all the processes.

Linked to some serious environmental problems, fulfill the 2030 agenda for Sustainable Development is a daily challenge for this industry.

Substantial efforts have been devoted to developing sustainable alternatives and avoid chemical bioaccumulation in nature and prevent serious health problems for humans and all ecosystems. The enzyme-based process, chemical replacements, combined technologies, and application of the circular economy concept were the approaches reported in the last five years.

Enzymatic methods showed clear evidence in the reduction of time demanding and environmental impact on the dehairing operation. Salt-free methods, performed with naphthalene sulfonic acid, combined with the recycling of chrome tanning effluent, presented itself as the best option for the tanning operation.

Despite promising results concerning the reduction of pollution load, it is unlikely that a new process will be able to satisfy all the features required and ensured by the conventional tanning process. Nevertheless, chemicals and processes cost-effective, and its availability is assumed to be one of the barriers to the sustainable movement, reflecting the importance of a binding agreement with four key elements: the involvedness of the tanners, the continuous innovation, the economic growth, and the strict environmental regulations.

However, the world around us is continually evolving. New knowledge, new theories, new techniques, and products are continually being evaluated and implemented. Moreover, if the leather world accepts all these new mechanisms, maybe soon we can say that the pollution is no longer a concern. Until then, the alternatives presented are a good starting point to get there. 


\section{References}

Andrioli, E., L. Petry, and M. Gutterres. 2015. "Environmentally friendly hide unhairing: Enzymatic-oxidative unhairing as an alternative to use of lime and sodium sulfide". Process Safety and Environmental Protection 93: https://doi.org/10.1016/j.psep.2014.06.001.

Anzani, C., B. Prandi, S. Buhler, T. Tedeschi, C. Baldinelli, G. Sorlini, A. Dossena, and S. Sforza. 2017. "Towards environmentally friendly skin unhairing process: A comparison between enzymatic and oxidative methods and analysis of the protein fraction of the related wastewaters". Journal of Cleaner Production 164 (october): 1446-54. https://doi.org/10.1016/j.jclepro.2017.07.071.

Bacardit, A., J. M. Morera, L. Olle, E. Bartoli, and M. Dolors Borras. 2008. "High chrome exhaustion in a non-float tanning process using a sulphonic aromatic acid". Chemosphere 73, no. 5 (october): 820-24. https://doi.org/10.1016/j.chemosphere.2008.07.036.

Bosnic, M., J. Buljan, and R. P. Daniels. 2000. Pollutants in tannery effluents. US/RAS/92/120. UNIDO: United Nations Industrial Development Organization. https://leatherpanel.org/content/pollutants-tannery-effluent.

Cao, S., B. Liu, B. Cheng, F. Lu, Y. Wang, and Y. Li. 2017. "Mechanisms of Zn(II) binded to collagen and its effect on the capacity of eco-friendly $\mathrm{Zn}-\mathrm{Cr}$ combination tanning system". Journal of Hazardous Materials 321 (january): 203-09. https://doi.org/10.1016/j.jhazmat.2016.09.016.

Cao, S., K. Wang, S. Zhou, Y. Wang, B. Liu, B. Cheng, and Y. Li. 2018. "Mechanism and effect of high-basicity chromium agent acting on $\mathrm{Cr}$-wastewater-reuse system of leather industry". ACS Sustainable Chemistry \& Engineering 6, no. 3 (march): 3957-63. https://doi.org/10.1021/acssuschemeng.7b04282.

Chandra, P., and K. Kulshreshtha. 2004. "Chromium accumulation and toxicity in aquatic vascular plants". The Botanical Review 70, no. 3 (july): 313-27. https://doi.org/10.1663/0006-8101(2004)070[0313:Caatia]2.0.Co;2.

Conseil National du Cuir. 2020. Fiches Pays 2018. https://conseilnationalducuir.org/sites/default/files/cnc/fichespays/conseilnationalducuir_ficheeco-2019_portugal.pdf.

- - 2019. Cuirs et peaux finis (tous cuirs et peaux confondus). https://conseilnationalducuir.org/sites/default/files/mediascnc/observatoire_economique/monographies/mono_ce_cpf_2018.pdf.

COTANCE (Confederation of National Associations of Tanners and Dressers of the European Community). 2016. Manifesto of the social partners of the leather industry at EU Level. https://www.euroleather.com/doc/AFFELmanifesto.pdf.

Covington, A. D. 2011. Tanning chemistry: The science of leather. Royal Society of Chemistry. https://pubs.rsc.org/en/content/ebook/978-1-84973-434-9.

Crudu, M., V. Deselnicu, D. C. Deselnicu, and L. Albu. 2014. "Valorization of titanium metal wastes as tanning agent used in leather industry". Waste Management 34, no. 10 (october): 1806-14. https://doi.org/10.1016/j.wasman.2013.12.015.

Dixit, S., A. Yadav, P. D. Dwivedi, and M. Das. 2015. "Toxic hazards of leather industry and technologies to combat threat: A review". Journal of Cleaner Production 87, issue C: 39-49. https://doi.org/10.1016/j.jclepro.2014.10.017. 
Durga, J., A. Ranjithkumar, R. Ramesh, K. T. P. V. Girivasan, C. Rose, and C. Muralidharan. 2016. "Replacement of lime with carbohydrases - a successful cleaner process for leather making". Journal of Cleaner Production 112 (january): 1122-27. https://doi.org/10.1016/j.jclepro.2015.07.018.

EPA (United States Environmental Protection Agency). 2014. "Priority pollutant list". https://www.epa.gov/sites/production/files/2015-09/documents/priority-pollutant-listepa.pdf.

Erdem, M. 2006. "Chromium recovery from chrome shaving generated in tanning process". Journal of Hazardous Materials 129, no. 1-3 (february): 143-46. https://doi.org/10.1016/j.jhazmat.2005.08.021.

European Commission. 2019. "The leather industry in the EU". https://ec.europa.eu/growth/sectors/fashion/leather/eu-industry_en.

- - . 2014. "Commission regulation (EU) No 301/2014 - Annex XVII to Regulation (EC) No 1907/2006".

https://eur-lex.europa.eu/legalcontent/EN/TXT/?uri=uriserv:OJ.L_.2014.090.01.0001.01.ENG\&toc=OJ:L:2014:090:TOC.

FAO (Food and Agriculture Organization of the United Nations). 2016. World statistical compendium for raw hides and skins, leather and leather footwear 1999-2015. https://www.fao.org/publications/card/en/c/2 bb7ce63-da1b-4d89-9510-afc725b5e960/.

Gao, D., Y. Cheng, P. Wang, F. Li, Y. Wu, B. Lyu, J. Ma, and J. Qin. 2020. "An eco-friendly approach for leather manufacture based on P(POSS-MAA)-aluminum tanning agent combination tannage". Journal of Cleaner Production 257 (june): Article number 120546. https://doi.org/10.1016/j.jclepro.2020.120546.

Giaccherini, F., G. Munz, T. Dockhorn, C. Lubello, and D. Rosso. 2017. "Carbon and energy footprint analysis of tannery wastewater treatment: A Global overview". Water Resources and Industry 17 (june): 43-52. https://doi.org/10.1016/j.wri.2017.03.001.

Hashem, A., N. Arman, H. R. Sheikh, and M. Islam. 2017. "Sodium chloride substitute for lower salt goat skin preservation: A novel approach". Journal of the American Leather Chemists $\begin{array}{lllll}\text { Association } & 112, & \text { no. } & \text { 270-76. }\end{array}$ https://journals.uc.edu/index.php/JALCA/article/view/3774.

Hashem, A., A. Momen, and M. Hasan. 2018. "Leaf paste aided goat skin preservation: Significant chloride reduction in tannery". Journal of Environmental Chemical Engineering 6, no. 4 (august): 4423-28. https://doi.org/10.1016/j.jece.2018.06.050.

Hülsen, T., K. Hsieh, and D. J. Batstone. 2019. "Saline wastewater treatment with purple phototrophic bacteria". Water Research 160 (september): 259-67. https://doi.org/10.1016/j.watres.2019.05.060.

Jayanthi, D., J. S. Victor, R. Chellan, and M. Chellappa. 2019. "Green processing: Minimising harmful substances in leather making". Environmental Science and Pollution Research 26, no. 7 (march): 6782-90. https://doi.org/10.1007/s11356-018-04111-z.

Jia, X., C. Zhang, S. Ali Chattha, and B. Peng. 2020. "A salt-free pickling chrome tanning technology: Pretreatment with the collective polyoxyethylene diepoxy ether and urotropine". Journal of Cleaner Production 244 (january): Article number 118706. https://doi.org/10.1016/j.jclepro.2019.118706.

Jian, S., T. Wenyi, and C. Wuyong. 2011. "Kinetics of enzymatic unhairing by protease in leather industry". Journal of Cleaner Production 19, no. 4 (march): 325-31. https://doi.org/10.1016/j.jclepro.2010.10.011. 
Joseph, K., and N. Nithya. 2009. "Material flows in the life cycle of leather". Journal of Cleaner Production 17, no. 7 (may): 676-82. https://doi.org/10.1016/j.jclepro.2008.11.018.

Kanagaraj, J., R. C. Panda, and T. Senthilvelan. 2016. "Green remediation of sulfide in oxidative dehairing of skin and correlation by mathematical model: An eco-friendly approach". Process Safety and Environmental Protection 100 (march): 36-48. https://doi.org/10.1016/j.psep.2015.12.005.

Kanagaraj, J., T. Senthilvelan, R. C. Panda, and S. Kavitha. 2015. "Eco-friendly waste management strategies for greener environment towards sustainable development in leather industry: a comprehensive review". Journal of Cleaner Production 89 (february): 117. https://doi.org/10.1016/j.jclepro.2014.11.013.

Kargi, F., and A. R. Dincer. 1996. "Effect of salt concentration on biological treatment of saline wastewater by fed-batch operation". Enzyme and Microbial Technology 19, no. 7 (november): 529-37. https://doi.org/10.1016/S0141-0229(96)00070-1.

Li, K., H. Chen, Y. Wang, Z. Shan, J. Yang, and P. Brutto. 2009. "A salt-free pickling regime for hides and skins using oxazolidine". Journal of Cleaner Production 17, no. 17 (november): 1603-06. https://doi.org/10.1016/j.jclepro.2009.06.004.

Liu, M., J. Ma, B. Lyu, D. Gao, and J. Zhang. 2016. "Enhancement of chromium uptake in tanning process of goat garment leather using nanocomposite". Journal of Cleaner Production 133 (october): 487-94. https://doi.org/10.1016/j.jclepro.2016.04.156.

LWG (Leather Working Group). 2019. "Environmental Audit Protocol". https://www.leatherworkinggroup.com/.

Miransari, M. 2017. "Arbuscular mycorrhizal fungi and soil salinity". In Mycorrhizal Mediation of Soil, edited by N. C. Johnson, C. Gehring and J. Jansa, 263-77. Elsevier. https://doi.org/10.1016/B978-0-12-804312-7.00015-2.

Morera, J. M., E. Bartolí, R. Chico, C. Solé, and L. F. Cabeza. 2011. "Minimization of the environmental impact of chrome tanning: A new process reusing the tanning floats". Journal of Cleaner Production 19, no. 17-18 (november): 2128-32. https://doi.org/10.1016/j.jclepro.2011.07.018.

Morera, J. M., E. Bartolí, and R. M. Gavilanes. 2016. "Hide unhairing: Achieving lower pollution loads, decreased wastewater toxicity and solid waste reduction". Journal of Cleaner Production 112: 3040-47. https://doi.org/10.1016/j.jclepro.2015.11.028.

Pang, B. W., C. H. Jiang, M. Yeung, Y. Ouyang, and J. Xi. 2017. "Removal of dissolved sulfides in aqueous solution by activated sludge: mechanism and characteristics". Journal of Hazardous Materials 324: 732-38. https://doi.org/10.1016/j.jhazmat.2016.11.048.

Ramesh, R. R., V. Muralidharan, and S. Palanivel. 2018. "Preparation and application of unhairing enzyme using solid wastes from the leather industry - an attempt toward internalization of solid wastes within the leather industry". Environmental Science and Pollution Research 25, no. 3 (january): 2121-36. https://doi.org/10.1007/s11356-017-05509.

Ranjithkumar, A., J. Durga, R. Ramesh, C. Rose, and C. Muralidharan. 2017. "Cleaner processing: a sulphide-free approach for depilation of skins". Environmental Science and Pollution Research 24, no. 1 (january): 180-88. https://doi.org/10.1007/s11356-016-76456.

Rao, J. R., P. Thanikaivelan, K. J. Sreeram, and B. U. Nair. 2002. "Green route for the utilization of chrome shavings (chromium-containing solid waste) in tanning industry". Environmental Science and Technology 36, no. 6 (march): 1372-76. https://doi.org/10.1021/es015635s. 
Rastogi, S. K., A. Pandey, and S. Tripathi. 2008. "Occupational health risks among the workers employed in leather tanneries at Kanpur". Indian Journal of Occupational and Environmental Medicine 12, no. 3 (september): 132-35. https://doi.org/10.4103/00195278.44695 .

Sarker, M., W. Long, G. Piazza, N. Latona, and C.-K. Liu. 2018. "Preservation of bovine hide using less salt with low concentration of antiseptic, part II: Impact of developed formulations on leather quality and the environment". Journal of the American Leather Chemists Association 113, no. 10 (october): $335-42$. https://journals.uc.edu/index.php/JALCA/article/view/1499.

Shakilanishi, S., N. K. Chandra Babu, and C. Shanthi. 2017. "Exploration of chrome shaving hydrolysate as substrate for production of dehairing protease by Bacillus cereus VITSN04 for use in cleaner leather production". Journal of Cleaner Production 149 (april): 797-804. https://doi.org/10.1016/j.jclepro.2017.02.139.

Silva, V. F. M., A. Crispim, and G. Pinto. 2019. "Application of oxazolidine in wet-white tanning". Leather and Footwear Journal 19, no. 4: 195-200. https://doi.org/10.24264/lfj.19.4.4.

Sivakumar, V., V. Sundar, T. Rangasamy, C. Muralidharan, and G. Swaminathan. 2005. "Management of total dissolved solids in tanning process through improved techniques". Journal of Cleaner Production 13, no. 7 (june): 699-703. https://doi.org/10.1016/j.jclepro.2004.01.006.

Statista. 2020a. "Number of enterprises in the manufacture of leather and related products industry in Portugal from 2008 to 2016". https://www.statista.com/statistics/371918/number-of-enterprises-in-the-leathermanufacturing-sector-in-portugal/.

Statista. 2020b. "Turnover of the manufacture of leather and related products industry in Portugal 2008-2016 (in million euros)". https://www.statista.com/statistics/386180/turnover-manufacturing-leather-industryportugal/.

Sujitha, P., S. Kavitha, S. Shakilanishi, N. K. C. Babu, and C. Shanthi. 2018. "Enzymatic dehairing: A comprehensive review on the mechanistic aspects with emphasis on enzyme specificity". International Journal of Biological Macromolecules 118 (october): 168-79. https://doi.org/10.1016/j.ijbiomac.2018.06.081.

Sundar, V. J., and C. Muralidharan. 2017. "Salinity free high tannin fixation vegetable tanning: Commercial success through new approach". Journal of Cleaner Production 142 (january): 2556-61. https://doi.org/10.1016/j.jclepro.2016.11.021.

- - . 2020. "An environmentally friendly mineral-free tanning of animal skins - Sustainable approach with plant resources". Environmental Processes 7, no. 1 (march): 255-70. https://doi.org/10.1007/s40710-020-00422-x.

Sundar, V. J., C. Muralidharan, and A. B. Mandal. 2013. "A novel chrome tanning process for minimization of total dissolved solids and chromium in effluents". Journal of Cleaner Production 59 (november): 239-44. https://doi.org/10.1016/j.jclepro.2013.07.002.

Syed, M., T. Saleem, Shuja-ur-Rehman, M. A. Iqbal, F. Javed, M. B. S. Khan, and K. Sadiq. 2010. "Effects of leather industry on health and recommendations for improving the situation in Pakistan". Archives of Environmental and Occupational Health 65, no. 3 (july-september): 163-72. https://doi.org/10.1080/19338241003730895. 
Tahiri, S., and M. De La Guardia. 2009. "Treatment and valorization of leather industry solid wastes: A review". Journal of the American Leather Chemists Association 104, no. 2: 52-67. https://journals.uc.edu/index.php/JALCA/article/view/2465.

Tchounwou, P. B., C. G. Yedjou, A. K. Patlolla, and D. J. Sutton. 2012. "Heavy metal toxicity and the environment". EXS 101: 133-64. https://doi.org/10.1007/978-3-7643-8340-4_6.

United Nations. 2016. Transforming our world: The 2030 agenda for sustainable development. https://sdgs.un.org/2030agenda.

Vijay Kumar, E., M. Srijana, K. Kiran Kumar, N. Harikrishna, and G. Reddy. 2011. "A novel serine alkaline protease from Bacillus altitudinis GVC11 and its application as a dehairing agent". Bioprocess and Biosystems Engineering 34, no. 4 (may): 403-09. https://doi.org/10.1007/s00449-010-0483-x.

Watt, B. E., A. T. Proudfoot, and J. A. Vale. 2004. "Hydrogen peroxide poisoning". Toxicological Reviews 23, no. 1: 51-57. https://doi.org/10.2165/00139709-200423010-00006.

Zhang, C., J. Lin, X. Jia, and B. Peng. 2016. "A salt-free and chromium discharge minimizing tanning technology: The novel cleaner integrated chrome tanning process". Journal of Cleaner Production 112 (january): 1055-63. https://doi.org/10.1016/j.jclepro.2015.07.155.

Zhang, C., F. Xia, J. Long, and B. Peng. 2017a. "An integrated technology to minimize the pollution of chromium in wet-end process of leather manufacture". Journal of Cleaner Production 154 (june): 276-83. https://doi.org/10.1016/j.jclepro.2017.03.216.

Zhang, H., X. Chen, X. Wang, X. Qiang, X. Li, and M. Li. 2017b. "A salt-free pickling chrome tanning approach using a novel sulphonic aromatic acid structure". Journal of Cleaner Production 142 (january): 1741-48. https://doi.org/10.1016/j.jclepro.2016.11.113.

Zuriaga-Agustí, E., M. V. Galiana-Aleixandre, A. Bes-Piá, J. A. Mendoza-Roca, V. RisueñoPuchades, and V. Segarra. 2015. "Pollution reduction in an eco-friendly chrome-free tanning and evaluation of the biodegradation by composting of the tanned leather wastes". Journal of Cleaner Production 87, no. 1 (january): 874-81. https://doi.org/10.1016/j.jclepro.2014.10.066.

\section{Acknowledgments}

The author would like to acknowledge ANI for the support of the Project FAMEST 24529 by Portugal 2020 Programme. 